\title{
KAJIAN TINGKAT KEPUASAN MAHASISWA TERHADAP LAYANAN PERPUSTAKAAN SEKOLAH TINGGI AGAMA ISLAM (STAIN) PALOPO
}

\author{
Oleh: Alia Lestari \\ Program Studi Pendidikan Matematika Fakultas Tarbiyah STAIN Palopo \\ e-mail: entjenk@gmail.com
}

\begin{abstract}
Abstrak:
Artikel ini mengkaji tentang persepsi mahasiswa terhadap layanan perpustakaan STAIN Palopo sehingga tingkat kepuasan mahasiswa terhadap layanan perpustakaan dapat diukur. Jumlah sampel yang digunakan sebesar $20 \%$ dari 2995 yang dilakukan dengan cara Incidental sampling. Dari hasil analisis data diperoleh bahwa mahasiswa pengguna layanan perpustakaan paling banyak adalah perempuan (74.7\%) dengan Indeks kepuasan mahasiswa terhadap atribut layanan perpustakaan yang paling rendah adalah pengetahuan petugas tentang jenis buku yang ada di perpustakaan dan yang paling tinggi adalah kemampuan petugas berkomunikasi dengan mahasiswa.
\end{abstract}

Kata Kunci: Indeks kepuasan, Layanan perpustakaan.

\section{Pendahuluan}

Perkembangan dan kemajuan zaman yang cukup pesat memberikan dampak yang tidak hanya positif, melainkan juga tidak sedikit dampak negatif bagi generasi muda dewasa ini. Kebebasan yang dilahirkan oleh era reformasi terkadang menjadi momok tersendiri bagi mahasiswa sebagai pencetusnya. Aksi demonstrasi yang seharusnya merupakan langkah terakhir setelah diplomasi tidak lagi dapat menyelesaikan masalah, kini seolah-olah menjadi ajang mahasiswa menunjukkan eksistensi dirinya, yang parahnya kebanyakan aksi ini malah merusak fasilitas umum. Hal ini tentu saja sangat memprihatinkan, karena tujuan dari reformasi yang sebenarnya adalah kebebasan yang bertanggung jawab, bukan kebebasan yang tidak terkontrol.

Perguruan tinggi sebagai tempat mahasiswa mencari ilmu sekaligus mengekspresikan diri, sudah selayaknya mencari solusi terhadap fenomena ini. Salah satu faktor yang seringkali memicu aksi ini adalah ketidakpuasan mahasiswa terhadap kebijakankebijakan yang dikeluarkan oleh pihak kampus dan kurangnya perhatian terhadap kualitas pelayanan fasilitas pendukung kegiatan kampus yang berhubungan langsung dengan mahasiswa, seperti layanan akademik dan perpustakaan.

Strategi yang dapat dilakukan untuk meminimalisir aksi-aksi demonstrasi mahasiswa ini adalah dengan meningkatkan kualitas layanan. Pelayanan yang baik dari petugasnya akan menjadikan 
pengguna (mahasiswa dan civitas akademika) benar-benar dapat belajar dengan baik. Di samping itu, datang ke perpustakaan menjadi kebiasaan yang dapat tumbuh dengan sendirinya bagi mahasiswa sehingga mereka akan menghabiskan lebih banyak waktu di perpustakaan.

Salah satu indikator yang paling banyak dipakai untuk mengukur kualitas layanan adalah tingkat kepuasan mahasiswa terhadap layanan tersebut, dan salah satu layanan yang sangat penting di sebuah perguruan tinggi adalah layanan perpustakaan. Kebutuhan konsumen khususnya mahasiswa terhadap ilmu pengetahuan dan media edukasi lainnya merupakan hal yang sulit untuk dipisahkan karena perpustakaan merupakan salah satu sarana penunjang akademik yang dibutuhkan oleh mahasiswa.

Memberikan pelayanan yang dapat memberikan kepuasan kepada mahasiswa bukanlah merupakan hal mudah, sering juga ditemukan masalah pada pelaksanaan yang membuat mahasiswa tidak nyaman. Oleh karena itu diperlukan perencanaan yang matang dan fasilitas yang memadai agar kepuasan mahasiswa dapat tercapai. Untuk meningkatkan pelayanan, maka diperlukan penilaian dari mahasiswa terhadap pelayanan yang diterima agar pengelola perpustakaan dapat menyediakan sarana dan pelayanan yang dibutuhkan oleh mahasiswa, serta membuat prioritas dalam program peningkatan pelayanan, karena sulit bagi pengelola untuk memenuhi semua keinginan mahasiswa karena berbagai keterbatasan.

Artikel ini akan mengkaji persepsi mahasiswa terhadap layanan perpustakaan STAIN Palopo sehingga tingkat kepuasan mahasiswa terhadap layanan perpustakaan dapat diukur.

\section{Bahan dan Metode}

\section{a. Konsep Kepuasan Pelanggan}

Bila sebuah produk atau jasa memenuhi atau melampaui harapan pelanggan, biasanya pelanggan merasa puas. Secara garis besar itulah definisi kepuasan pelanggan. ${ }^{1}$. Menurut Kotler dalam Fredi Rangkuti kepuasan pelanggan adalah:" ... a person's feeling of pleasure or dissapointment resulneliting from comparing a product's received performance (or outcome) in relations to the persons's expectation"- perasaan senang atau kecewa seseorang

\footnotetext{
${ }^{1}$ Gerson, Richard F, Mengukur Kepuasan Pelanggan, PPM Griffin, Jill, 2002. hal.221
} 
125 | al-Khwarizmi, Volume III, Edisi 1, Maret 2015, Hal. 123 - 142.

sebagai hasil dari perbandingan antara prestasi atau produk yang dirasakan dan yang diharapkannya. ${ }^{2}$

Pada dasarnya pengertian kepuasan pelanggan mencakup perbedaan antara tingkat kepentingan dan kinerja atau hasil yang dirasakan. Engel dan Pawitra dalam Rangkuti F. juga mengatakan bahwa pengertian tersebut dapat diterapkan dalam penilaian kepuasan atau ketidakpuasan terhadap satu perusahaan tertentu karena keduanya berkaitan erat dengan konsep kepuasan pelanggan $^{3}$, sebagaimana dapat dilihat pada Gambar berikut

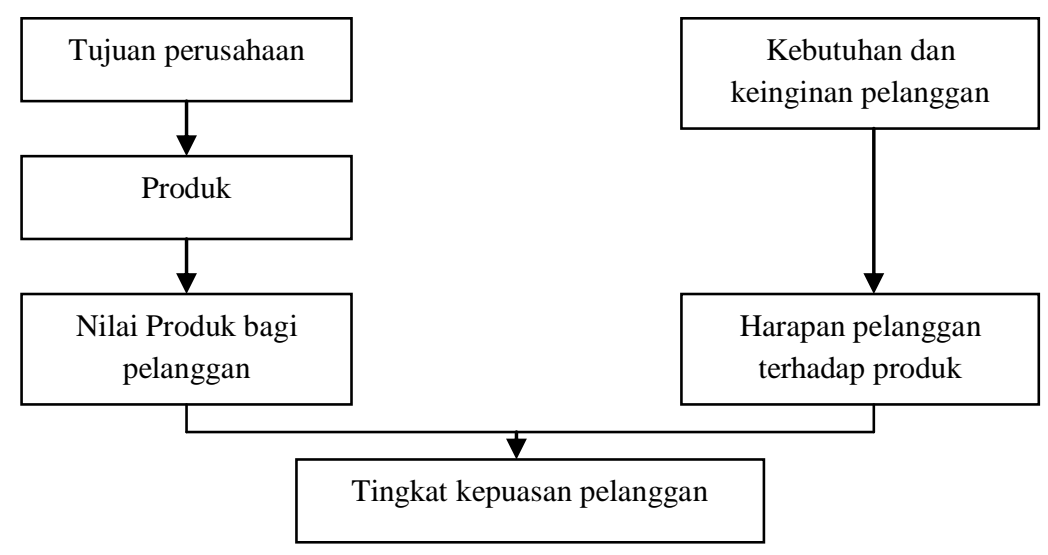

Gambar 1. Diagram Konsep Kepuasan pelanggan

\section{b. Konsep kepuasan pelanggan di bidang jasa}

Jasa merupakan pemberian suatu kinerja atau tindakan tak kasat meta dari satu pihak ke pihak lain. Pada umumnya hasa diproduksi dan dikonsumsi secara bersamaan, dimana interaksi antara pemberi jasa dan penerima jasa mempengaruhi hasil jasa tersebut. $^{4}$

STAIN Palopo sebagai suatu lembaga pendidikan, dalam hal ini dianggap sebagai suatu perusahaan jasa dan mahasiswa adalah pelanggan, akan sukses bila:

1) Janji perusahaan mengenai jasa yang akan disampaikan kepada pelanggan.

\footnotetext{
${ }^{2}$ Rangkuti F. Measuring Customer Satisfaction (Teknik Mengukur dan Meningkatkan Kepuasan Pelanggan), Gramedia Pustaka Utama, Jakarta, 2006. h. 87

${ }^{3}$ Ibid

${ }^{4}$ Ibid h.92
} 
2) Kemampuan perusahaan untuk membuat karyawan mampu memenuhi janji tersebut.

3) Kemampuan karyawan untuk menyampaikan janji tersebut kepada pelanggan.

Ada Sepuluh kriteria umum atau standar yang menentukan kualitas suatu jasa, yaitu:

1. Keandalan (Reliability)

2. Ketanggapan (Responsiveness)

3. Kemampuan (Competence)

4. Mudah diperoleh (Acces)

5. Keramahan (Courtesy)

6. Komunikasi (Communication)

7. Dapat dipercaya (Credibility)

8. Keamanan (Security)

9. Memahami pelanggan (Understanding)

10. Bukti nyata kasat mata (Tangibles)

Kesepuluh dimensi tersebut akan disederhanakan menjadi 5 dimensi,yaitu:

1. Ketanggapan (Responsiveness), yaitu kemampuan untuk menolong pelanggan dan ketersediaan untuk menolong pelanggan dengan baik.

2. Keandalan (Reliability), yaitu kemampuan untuk melakukan pelayanan sesuai yang dijanjikan dengan segera, akurat dan memuaskan.

3. Empaty (Emphaty), yaitu rasa perduli untuk memberikan perhatian secara individual kepada pelanggan, memahami kebutuhan pelanggan serta kemudahan untuk dihubungi.

4. Jaminan (Assurance), yaitu pengetahuan, kesopanan petugas serta sifatnya yang dapat dipercaya sehingga pelanggan terbebas dari resiko.

5. Bukti langsung (Tangibles), meliputi fasilitas fisik, perlengkapan karyawan, dan sarana komunikasi. ${ }^{5}$

\section{c. Model kesenjangan kepuasan pelanggan}

Menurut Bilson Simamora dalam Rangkuti F., ada beberapa model yang dapat dipergunakan untuk menganalisis kualitas jasa, tergantung pada tujuan analisis, jenis perusahaan dan situasi pasar, yaitu:

1. Gap antara konsumen dan persepsi manajemen 
127 |al-Khwarizmi, Volume III, Edisi 1, Maret 2015, Hal. 123 - 142.

2. Gap antara persepsi manajemen terhadap harapan konsumen dan spesifikasi kualitas jasa.

3. Gap antara spesifikasi kualitas jasa dan penyampaian jasa

4. Gap antara penyampaian jasa dan komunikasi internal

5. Gap antara jasa yang dirasakan dan jasa yang diharapkan ${ }^{6}$

Pada makalah ini, pengukuran yang dilakukan adalah gap antara jasa yang dirasakan dan jasa yang diharapkan. Kepuasan pelanggan terhadap suatu jasa ditentukan oleh tingkat kepentingan pelanggan sebelum menggunakan jasa dibandingkan dengan hasil persepsi pelanggan terhadap jasa tersebut setelah pelanggan merasakan kinerja jasa tersebut
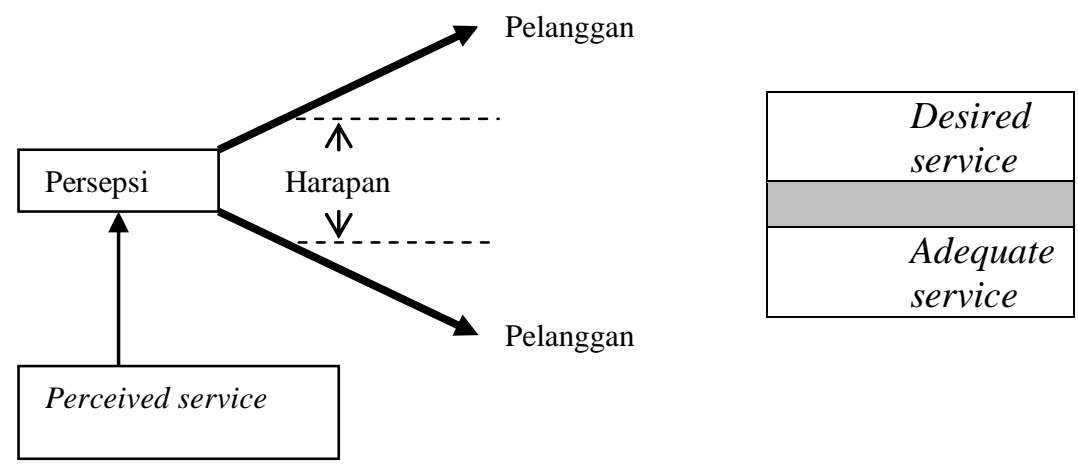

Gambar 2. Diagram proses kepuasan pelanggan

Salah satu faktor yang menentukan kepuasan pelanggan adalah kualitas pelayanan yang terdiri dari 5 dimensi pelayanan. Kesenjangan merupakan ketidaksesuaian antara pelayanan yang dipersepsikan (perceived service) dan pelayanan yang diharapkan (expected service).

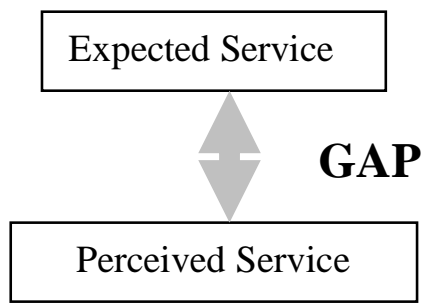

Gambar 3. Diagram kesenjangan yang dirasakan oleh pelanggan

${ }^{6}$ Ibid h.94 
Kesenjangan terjadi apabila pelanggan mempersepsikan apa yang diterimanya lebih tinggi daripada desired service atau lebih rendah daripada adequate service kepentingan pelanggan tersebut.

Pada pengukuran kepuasan pelanggan dilakukan pengukuran pada tingkat harapan dan kepuasan pelanggan. Dari beberapa persepsi tingkat harapan pelanggan, kita dapat merumuskan harapan yang paling dominan. Selanjutnya, kita dapat mengkaitkan harapan pelanggan pada variable ini dengan servis yang diterimanya dengan melihat matriks pada gambar 3 Matriks ini terdiri dari 4 kuadran: kuadran pertama terletak disebelah kiri atas, kuadran kedua disebelah kanan aats, kuadran ketiga disebelah kiri bawah dan kuadran keempat disebelah kanan bawah. Strategi yang dilakukan berkenaan dengan posisi masing-masing variabel adalah sebagai berikut:

\section{Kuadran 1 (Atributes to improve)}

Ini adalah wilayah yang memuat faktor-faktor yang dianggap penting oleh pelanggan, tetapi pada kenyataanya faktor-faktor ini belum sesuai seperti yang ia harapkan (tingkat kepuasan yang diperoleh masih sangat rendah). Variabel-variabel yang masuk dalam kuadran ini harus ditingkatkan. Caranya adalah perusahaan atau institusi melakukan perbaikan secara terus menerus sehingga performance variabel dalam kuadran ini akan meningkat.

\section{Kuadran 2 (maintain performance)}

Ini adalah wilayah yang memuat faktor-faktor yang dianggap penting oleh pelanggan dan faktor-faktor yang dianggap oleh pelanggan sudah sesuai dengan yang dirasakannya sehingga tingkat kepuasannya relatif lebih tinggi. Variabel-variabel yang termasuk dalam kuadran ini harus tetap dipertahankan karena semua variabel ini menjadikan jasa tersebut unggul dimata pelanggan.

\section{$>$ Kuadran 3 (Atributes to maintain)}

Ini adalah wilayah yang memuat faktor-faktor yang dianggap kurang penting oleh pelanggan dan pada kenyataannya kinerjanya tidak terlalu istimewa. Peningkatan variabel-variabel yang termasuk didalam ini dipertimbangkan kembali karena pengaruhnya terhadap manfaat yang dirasakan oleh pelanggan sangat kecil.

\section{> Kuadran 4 (Atributes to De-emphasize)}

Ini adalah wilayah yang memuat faktor-faktor yang dianggap kurang penting oleh pelanggan dan dirasakan terlalu berlebihan. Variabel-variabel yang termasuk dalam kuadran ini dapat dikurangi agar perusahaan dapat menghemat biaya 
129 | al-Khwarizmi, Volume III, Edisi 1, Maret 2015, Hal. 123 - 142.

High

\begin{tabular}{|l|l|}
\hline $\begin{array}{l}\text { High leverage } \\
\text { Atributes to improve }\end{array}$ & Atributes to maintain \\
\hline Maintain performance & $\begin{array}{l}\text { Low leverage } \\
\text { Atributes to De- } \\
\text { emphasize }\end{array}$ \\
\hline
\end{tabular}

Low

Performance

High

Gambar 3. Diagram importance/performance matriks

\section{d. Analisis Diskriminan}

Analisis Diskriminan bertujuan untuk memisahkan atau mengklasifikasikan beberapa kelompok data yang sudah terkelompokkan dengan cara membentuk kombinasi linear fungsi diskriminan, sedemikian hingga setiap objek menjadi anggota dari salah satu kelompok. Karakteristik yang akan dipakai sebagai pembeda jenis datanya harus berskala interval atau rasio.

Analisis diskriminan dengan $\mathrm{p}$ variabel yang diukur dikembangkan berdasarkan asumsi / syarat yang mendasari analisis tersebut, yaitu data berdistribusi multivariate normal dan matriks varian kovarians antar kelompok. ${ }^{7}$ Kedua asumsi tersebut diperlukan untuk mendapatkan kombinasi linear fungsi diskriminan yang optimal dengan kesalahan klasifikasi (misclassification error rate) terkecil.

\section{e. Uji Distribusi Multinormal.}

Sebelum dilakukan analisis diskriminan, jika terdapat banyak variabel yang mendukung diperlukan asumsi distribusi multinormal [Johnson, 1998]. ${ }^{8}$ Kemultinormalan data dapat diuji dengan menghitung nilai jarak kuadrat pada setiap pengamatan, yaitu :

$$
d_{j}{ }^{2}=\left(\mathbf{x}_{\mathbf{j}}-\overline{\mathbf{x}}\right) \mathbf{S}^{-1}\left(\mathbf{x}_{\mathbf{j}}-\overline{\mathbf{x}}\right), j=1,2, \ldots, n
$$

dimana

$$
\begin{array}{cl}
\mathbf{x}_{\mathbf{j}} & : \text { pengamatan ke-j } \\
\mathbf{S}^{-1} & : \text { invers matriks varian kovarians }
\end{array}
$$

Hipotesis pada pengujian ini:

$\mathrm{H}_{0}$ : data berdistribusi multivariate normal.

$\mathrm{H}_{1}$ : data tidak berdistribusi multivariate normal.

\footnotetext{
${ }^{7}$ William R. Dillon, Multivariate Analysis Methods and Applications, John Wiley \& Sons, New York 1984 h.236

${ }^{8}$ Richard A. Johnson, Applied Multivariate Statistical Analysis, Prentice Hall, New York, 1998, h.153
} 
Hipotesis nol akan ditolak dengan $\alpha=0.05$ jika lebih dari 50\% nilai dari $\mathrm{d}_{\mathrm{i}}^{2}$ lebih besar dari $\chi^{2}(0.05, \mathrm{p})$.

\section{f. Uji Kesamaan Matriks Varian Kovarians.}

Untuk menguji kehomogenan matriks varian kovarians antar kelompok digunakan Statistik uji Box's $\mathrm{M}^{9}$

Perumusan hipotesisnya adalah :

$\mathrm{H}_{0}: \Sigma_{\mathbf{1}}=\Sigma_{\mathbf{2}}=\ldots=\Sigma_{\mathrm{k}}$

$\mathrm{H}_{1}$ : minimal ada satu kelompok yang berbeda, $\Sigma_{\mathrm{i}} \neq \Sigma_{\mathrm{j}} ; \mathrm{i}, \mathrm{j}, \ldots, \mathrm{k}$

Statistik uji Box's M :

$$
\begin{aligned}
\text { Box's } \mathrm{M} & =-2 \ln \Lambda^{*}=(n-k) \ln \left|\frac{W}{n-k}\right|-\sum_{j=1}^{k}\left(n_{j}-1\right) \ln \left|S_{j}\right| \\
\Lambda^{*} & =\prod_{j=1}^{k} \frac{|\mathbf{S j}|^{(n-1) / 2}}{\mid \mathbf{W} /(\mathbf{n}-\mathbf{k})^{(n-k) / 2}}
\end{aligned}
$$

dimana : $\mathrm{k} \quad$ : banyak kelompok

$$
\frac{\mathbf{W}}{(\mathbf{n}-\mathbf{k})} \text { : matriks kovarians gabungan dalam kelompok }
$$

$\mathbf{S}_{\mathrm{j}}$ : matriks kovarians kelompok ke-j

Tolak Ho jika $\left(\frac{-2 \ln \Lambda^{*}}{b}\right) \geq F_{v_{1}, v_{2}, \alpha}$, yang artinya matriks varian kovarians antar kelompok tidak homogen.

\section{g. Analisis Diskriminan Bertahap (Stepwise Discriminant Analysis)}

Analisis diskriminan bertahap (Stepwise Discriminant) digunakan apabila dalam pengklasifikasian obyek melibatkan banyak peubah, maka untuk menentukan kriteria peubah mana yang mempunyai peranan cukup besar dalam pembentukan fungsi diskriminan digunakan. Analisis ini berusaha mengeluarkan peubah yang kurang berguna dalam pembentukan fungsi diskriminan sebelum dilakukan analisis selanjutnya (Dillon, 1984). Analisis diskriminan bertahap ini bertujuan untuk mendapatkan fungsi diskriminan yang terbaik, yaitu fungsi diskriminan yang dapat mengklasifikasikan obyek kedalam kelompok yang relatif

\footnotetext{
${ }^{9}$ Ibid h.156
} 
131 | al-Khwarizmi, Volume III, Edisi 1, Maret 2015, Hal. 123 - 142.

homogen dengan menggunakan beberapa variabel yang signifikan berpotensi sebagai variabel pembeda.

Kriteria seleksi peubah yang akan masuk dalam fungsi diskriminan dalam memilih variabel pembeda yaitu yang mempunyai nilai $\mathrm{F}$ besar atau nilai Wilks' Lambda yang terkecil. Selanjutnya variabel pembeda kedua dipilih yang paling berarti berikutnya, dimana variabel tersebut mampu untuk meningkatkan kriteria pembedaan setelah dikombinasikan dengan peubah terpilih pertama. Demikian seterusnya sampai tidak ada lagi variabel yang mampu untuk meningkatkan perbedaan setelah dikombinasikan dengan variabel terpilih sebelumnya atau pada setiap langkah, peubah terpilih dapat dikeluarkan dari analisis, jika ternyata dengan masuknya variabel tersebut justru melemahkan daya pembedaan setelah dikombinasikan dengan peubah sebelumnya.

Nilai $\mathrm{F}$ adalah pendekatan dari statistik Wilks' Lambda, yaitu :

$$
\mathbf{\Lambda}=\frac{|\mathbf{W}|}{|\mathbf{W}+\mathbf{B}|}
$$

dimana $\mathrm{W}$ adalah matriks peragam dalam kelompok dan $\mathrm{B}$ adalah matrik peragam antar kelompok.

\section{h. Uji $t$ (T test)}

Uji t memberikan suatu metode yang memungkinkan kita dapat menarik kesimpulan dalam membandingkan dua kelompok data (J. Supranto, 2001). Dengan menggunakan uji t, dapat diperoleh informasi apakah perbedaan yang terjadi pada dua kelompok itu cukup signifikan. Urutan langkah kegiatan dalam pengujian hipotesis adalah:

1. Merumuskan hipotesis, dengan:

$\mathrm{H}_{0}: \mu 1-\mu 2=0$

H1 $: \mu 1-\mu 2 \neq 0$

2. Mengumpulkan data, mencari bukti/ kenyataan yang terjadi dan menghitung kriteria uji t tes dengan menggunakan rumus:

$$
\begin{aligned}
& t_{0}=\frac{\bar{x}_{1}-\bar{x}_{2}}{\sqrt{\left(\left[\frac{S S_{1}+S S_{2}}{n_{1}+n_{2}-2}\right]\left[\frac{1}{n_{1}}+\frac{1}{n_{2}}\right]\right)}} \\
& n=n_{1}+n_{2}=\text { Banyaknya elemen sampel } 1 \text { dan } 2 \\
& \bar{x}_{1}=\sum x_{i 1} / n_{1}, \bar{x}_{2}=\sum x_{i 2} / n_{2}
\end{aligned}
$$




$$
S S_{1}=\sum\left(\bar{x}_{i 1}-\bar{x}_{1}\right)^{2}, S S_{2}=\sum\left(\bar{x}_{i 2}-\bar{x}_{2}\right)^{2}
$$

3. Tentukan nilai alpha $(\alpha)$, cari nilai kriteria t dari tabel dengan menggunakan derajat kebebasan tertentu.

4. Bandingkan nilai $t$ tabel dengan $t$ hitung dan tolak $\mathrm{H}_{0}$ jika $\mathrm{t}$ hitung $>\mathrm{t}$ tabel

\section{i. $\quad$ Indeks kepuasan pelanggan}

Pengukuran indeks dalam kepuasan pelanggan atau kinerja berguna untuk menentukan target kepuasan yang akan dicapai periode selanjutnya. Indeks kepuasan juga lebih berguna apabila proses pengukuran bersifat kontinyu. Proses tracking ini baru menghasilkan sesuatu yang bermanfaat bila dapat disimpulkan bahwa apa yang dilakukan perusahaan sudah benar. Hal ini akan tercermin dari indeks kepuasan pelanggan yang meningkat atau menurun. Bila meningkat tajam, maka ada indikasi awal bahwa program kepuasan pelanggan berjalan dengan efektif. Bila turun, maka sebaliknya ${ }^{10}$.

Institusi pendidikan kemungkinannya kecil untuk melakukan market standing survey, karena itu pada makalah ini survey dilakukan dengan mempergunakan mahasiswa STAIN Palopo sebagi pelanggan dari perpustakaan itu sendiri.

Mengukur kepuasan pelanggan yang harus diperhatikan adalah Quality satisfaction score, perceived best score dan value satisfaction score. Dilatarbelakangi oleh penelitian yang dilakukan di institusi pendidikan negeri dan metode survey yang bukan market standing survey, maka pengukuran indeks didasarkan pada Quality satisfaction score.

Quality satisfaction score dihitung dengan menggunakan konsep servqual. Dengan konsep ini indeks kepuasan mahasiswa diperoleh dari skor persepsi dan skor harapan terhadap lima dimensi yang mempengaruhi persepsi pelanggan terhadap kualitas pelayanan. Hasil perhitungan gap dari setiap atribut kemudian dirata-rata untuk menghitung gap setiap dimensi. Setelah itu, gap setiap dimensi dirata-rata untuk mendapatkan gap total. Perhitungan indeks memperhatikan tingkat kepentingan dengan dikalikan skor gapnya. ${ }^{11}$

\footnotetext{
${ }^{10}$ Irawan Handi, 10 Prinsip Kepuasan Pelanggan, PT. Elex Media Komputindo, Jakarta, 2003 h.63

${ }^{11}$ Ibid h.65
} 
133 | al-Khwarizmi, Volume III, Edisi 1, Maret 2015, Hal. 123 - 142.

j. Populasi dan Sampel

Sampling frame dibentuk berdasarkan data jumlah mahasiswa STAIN Palopo. Populasi sasaran survey adalah mahasiswa S1 STAIN Palopo sebagai salah satu customer dan merupakan pengguna langsung layanan perpustakaan STAIN. Jumlah populasi sasaran survei adalah 2995 mahasiswa S1.

Tabel 1. Jumlah Mahasiswa STAIN Palopo di masing-masing Jurusan.

\begin{tabular}{|c|c|}
\hline Jurusan & Total \\
\hline Tarbiyah & 1992 \\
\hline Syariah & 723 \\
\hline Dakwah & 218 \\
\hline Ushuluddin & 62 \\
\hline Jumlah & $\mathbf{2 9 9 5}$ \\
\hline
\end{tabular}

Jumlah sampel yang akan diambil adalah sebesar $20 \%$ dari populasi. Metode sampling dilakukan dengan Incidental sampling yang pengambilan sampelnya secara kebetulan, yaitu dengan melakukan wawancara dan membagikan kuisioner terhadap mahasiswa yang ditemui di perpustakaan sampai jumlah sampel yang dibutuhkan terpenuhi.

\section{k. Analisis Data}

Dalam analisa data ini, yang pertama dilakukan adalah mencari faktor yang membedakan mahasiswa yang puas dan tidak puas. Kemudian mengurutkan atribut layanan beredasarkan preferensi mahasiswa. Dari analisis gap dan preferensi mahasiswa, dihitung indeks kepuasan mahasiswa untuk mengetahui tingkat kepuasan mahasiswa terhadap tiap unit layanan fasilitas pendukung.

1) Analisis untuk validitas

Uji validitas dilakukan untuk mengukur apakah variablevariabel yang dipergunakan untuk mengukur kepuasan pelanggan pada kuisioner benar-benar mengukur variabel yang seharusnya diukur.

Pada pengujian validasi teknik yang dipakai adalah teknik korelasi dengan hipotesa sebagai berikut:

$\mathrm{H}_{0} \quad$ :Atribut tidak mengukur aspek yang sama

$\mathrm{H}_{1} \quad$ :Atribut mengukur aspek yang sama 
Hasil pengujian validitas variabel layanan perpustakaan dengan bantuan SPSS Release 20.0 dapat dilihat pada Tabel 4.1

Kriteria penolakan $\mathrm{H}_{0}$ adalah jika $\mathrm{r}$ hitung $>\mathrm{r}$ tabel. Dengan derajat bebas 168 dan nilai alpha 5\% maka didapat nilai $\mathrm{r}$ tabel $=0.15979$. Karena semua nilai hasil $r$ tiap item variable $>r$ tabel, maka dapat disimpulkan indikator variabel layanan perpustakaan valid dan dapat digunakan untuk pengukuran selanjutnya.

Tabel 2. Angka korelasi atribut layanan perpustakaan untuk persepsi dan harapan

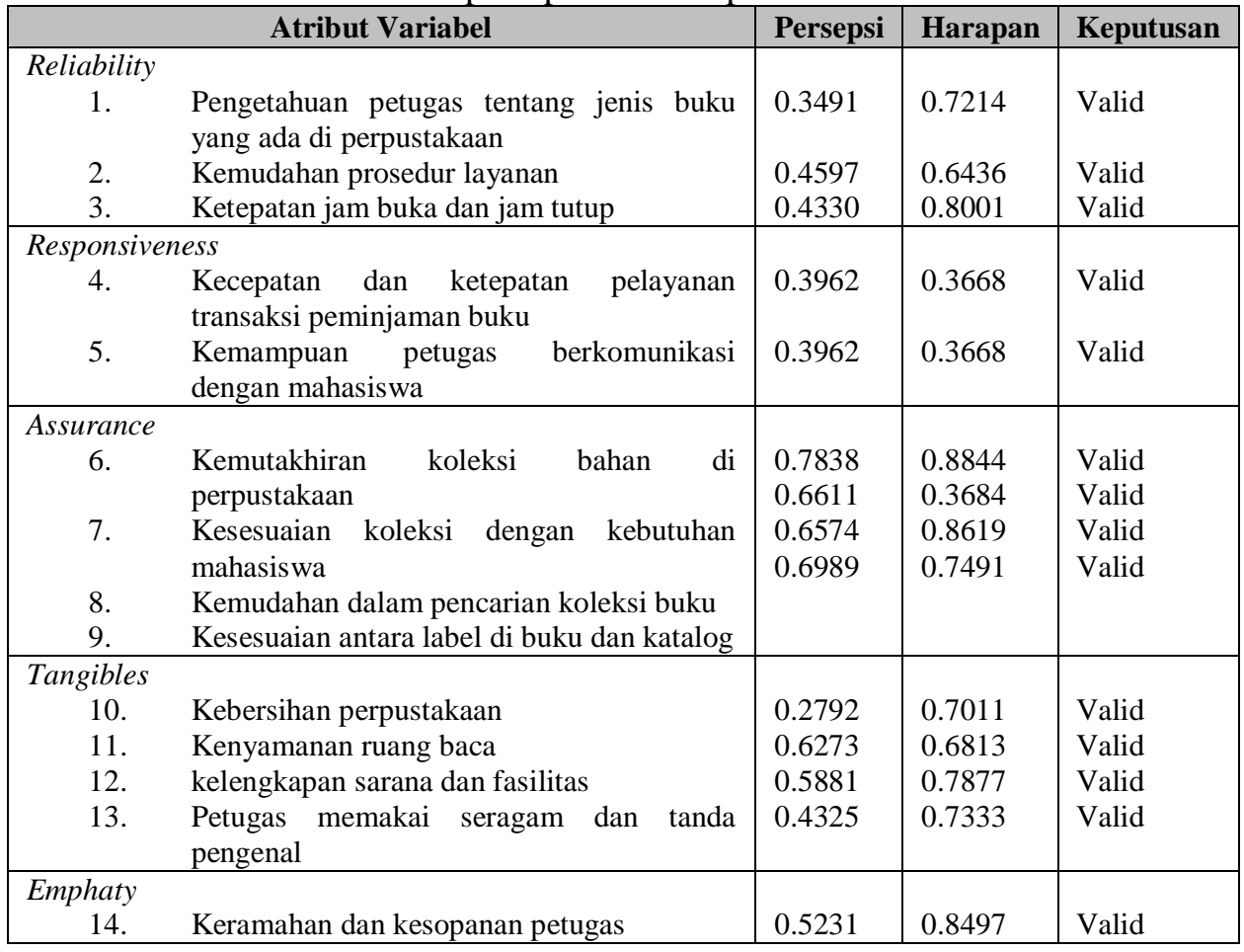

2) Uji Reliabilitas

Uji reliabilitas dilakukan untuk menguji ketepatan alat ukur yang digunakan dalam makalah ini. Koefisien reliabilitas diketahui dari besarnya koefisisen alpha $(\alpha)$. Apabila koefisien alpha lebih besar dari $r$ tabel maka dapat dikatakan reliabel. Dengan bantuan SPSS release 20.0 diketahui koefisien reliabilitas alat ukur dalam makalah ini adalah sebagai berikut. 
135 | al-Khwarizmi, Volume III, Edisi 1, Maret 2015, Hal. 123 - 142.

Tabel 3. Uji reliabilitas atribut layanan perpustakaan untuk persepsi dan harapan

\begin{tabular}{|l|l|l|l|}
\hline \multicolumn{1}{|c|}{ Variabel } & \multicolumn{1}{c|}{ Persepsi } & \multicolumn{1}{c|}{ Harapan } & Kesimpulan \\
\hline Reliability & 0.6027 & 0.8485 & Reliabel \\
\hline Responsiveness & 0.5671 & 0.5099 & Reliabel \\
\hline Assurance & 0.8366 & 0.8052 & Reliabel \\
\hline Tangibles & 0.6851 & 0.8530 & Reliabel \\
\hline Emphaty & 0.7664 & 0.9028 & Reliabel \\
\hline
\end{tabular}

Hasil pengujian reliabilitas variabel reliability, responsiveness, assurance, tangible dan emphaty ditunjukkan pada Tabel 3 dan diketahui bahwa semua nilai $\mathrm{r}$ alpha $>\mathrm{r}$ tabel (0.15979) sehingga dapat disimpulkan variabel pengukur layanan perpustakaan dan dapat dilakukan analisis selanjutnya.

3) Karakteristik mahasiswa pengguna layanan perpustakaan

Karakteristik responden pengguna layanan perpustakaan dapat dilihat berdasarkan demografi dan perilakunya.

Tabel 4 Karakteristik responden pengunjung perpustakaan

\begin{tabular}{|c|c|c|c|}
\hline & & Jumlah & Presentase \\
\hline \multirow{2}{*}{ Jenis Kelamin } & Laki-laki & 43 & 25.3 \\
\hline & Perempuan & 127 & 74.7 \\
\hline \multirow{3}{*}{$\begin{array}{l}\text { Status tempat } \\
\text { tinggal }\end{array}$} & Kos / kontrak & 120 & 70.6 \\
\hline & Rumah sendiri & 45 & 26.5 \\
\hline & Rumah saudara & 5 & 2.9 \\
\hline \multirow{5}{*}{ Pengeluaran } & $<$ Rp.100.000,- & 6 & 3.5 \\
\hline & Rp.100.000,- s/d <Rp.200.000,- & 42 & 24.7 \\
\hline & Rp.200.000,- s/d <Rp 300.000,- & 46 & 27.1 \\
\hline & Rp.300.000,- s/d <Rp. 400.000,- & 30 & 17.6 \\
\hline & $>$ Rp.400.000,- & 46 & 27.1 \\
\hline \multirow{3}{*}{$\begin{array}{l}\text { Frekwensi } \\
\text { kunjungan } \\
\text { dalam } 1 \text { bulan }\end{array}$} & 1 kali & 79 & 46.5 \\
\hline & $2-3$ kali & 69 & 40.6 \\
\hline & $>=4$ kali & 22 & 12.9 \\
\hline
\end{tabular}

Dalam Tabel 4 ditunjukkan bahwa mahasiswa pengguna layanan perpustakaan kebanyakan adalah perempuan, tepatnya dua kali lebih banyak dari laki-laki mengingat populasi dari mahasiswa STAIN Palopo sendiri secara keseluruhan hampir $70 \%$ adalah perempuan. Dari hasil wawancara, mahasiswa laki-laki di STAIN Palopo cenderung enggan untuk mencari tempat lain selain yang telah disediakan, kebalikan dari mahasiswa perempuan yang 
cenderung mencari variasi dalam memilih dan memutuskan sesuatu.

Mahasiswa yang tinggal kos atau kontrak, presentasenya lebih besar daripada yang tinggal dirumah sendiri dan rumah saudara, karena mahasiswa STAIN PALOPO yang tinggal di rumah sendiri lebih banyak menggunakan fasilitas-fasilitas di dekat rumah mereka. Selain itu, presentase mahasiswa STAIN PALOPO lebih banyak yang kos daripada yang tinggal dirumah sendiri atau rumah saudara. Pengeluaran perbulan mahasiswa pengguna layanan perpustakaan dapat dilihat pada Tabel 4.3. Mahasiswa yang pengeluarannya diatas Rp.400.000,- adalah mahasiswa yang kos atau kontrak, sedangkan yang pengeluarannya dibawah Rp. 100.000,- adalah mahasiswa yang tinggal dirumah sendiri.

4) Analisis diskriminan untuk menilai atribut layanan yang mempengaruhi kepuasan mahasiswa terhadap fasilitas perpustakaan STAIN Palopo.

Penilaian mahasiswa STAIN Palopo terhadap fasilitas perpustakaan, dapat dijadikan dasar untuk menilai variabel layanan mana yang sangat berpengaruh terhadap penilaian puas atau tidaknya mahasiswa terhadap layanan tersebut. Analisis diskriminan sebagai salah satu alat statistik dapat digunakan untuk mencari variabel-variabel pembeda dan menurunkannya kedalam persamaan linier.

Sebelum melakukan analisis diskriminan, ada dua asumsi yang harus dipenuhi, yaitu variabel independen harus multinormal dan matriks varian kovarian antar kelompok mahasiswa yang puas dan tidak puas harus sama.

Pengujian kemultinormalan dilakukan dengan menggunakan hipotesis:

$\mathrm{H}_{0} \quad$ : Data bersifat multinormal

$\mathrm{H}_{1} \quad$ : Data tidak berdistribusi multinormal

Dengan $\alpha=0,05$, jika lebih dari $50 \%$ nilai $\mathrm{d}_{\mathrm{i}}{ }^{2}$ (lihat bab 2 persamaan 3) lebih besar dari $\lambda^{2}(0.05,15)$ maka hipotesis nol akan ditolak. Dari hasil tersebut diperoleh kesimpulan bahwa untuk variabel independen layanan fasilitas perpustakaan tersebut berdistribusi multinormal karena nilai $\mathrm{d}_{\mathrm{i}}^{2}$ yang dibawah $\lambda^{2}(0.05,15)$ sebanyak 57.64\%. Hal ini juga didukung dengan plot yang mendekati garis lurus.

Pengujian kesamaan matriks dilakukan dengan menggunakan statistik uji Box's M dengan hipotesis:

$\mathrm{H}_{0} \quad: \Sigma_{\mathbf{1}}=\boldsymbol{\Sigma}_{\mathbf{2}}$ 
$137 \mid$ al-Khwarizmi, Volume III, Edisi 1, Maret 2015, Hal. 123 - 142.

$\mathrm{H}_{1} \quad: \Sigma_{1} \neq \Sigma_{2}$

Daerah penolakan $\mathrm{H}_{0}$ adalah jika signifikan lebih besar $\alpha$. Dengan $\alpha=5 \%$, dapat dilihat bahwa nilai signifikan pengujian kesamaan matriks untuk layanan perpustakaan adalah 0.119, sehingga dapat disimpulkan matriks varian kovarian antar kelompok pada tiap fasilitas adalah sama dan data ini memenuhi asumsi kedua, oleh karena itu dapat dilakukan analisis selanjutnya.

Berdasarkan hasil analisis diskriminan dengan menggunakan metode stepwise, diperoleh 4 variabel dari 14 variabel persepsi mahasiswa STAIN PALOPO terhadap layanan perpustakaan yang terseleksi sebagai variabel pembeda yang dapat dimasukkan dalam fungsi diskriminan. Kriteria pemilihan variabel pembeda adalah yang mempunyai nilai $\mathrm{F}$ terbesar dan wilks lambda terkecil. Variabel-variabel yang mempengaruhi kepuasan mahasiswa terhadap layanan ini dapat dilihat pada persamaan fungsi diskriminan sebagai berikut:

Fungsi $=\mathbf{- 5 . 3 1 2}+\mathbf{0 . 4 2 2}$ Keramahan dan kesopanan petugas + 0.303 Kemutakhiran koleksi bahan di perpustakaan +0.265 Kemudahan dalam pencarian koleksi buku $+\mathbf{0 . 2 5 5}$ Kelengkapan sarana dan fasilitas

Dari fungsi diskriminan diatas, maka dapat disimpulkan bahwa atribut layanan yang membedakan mahasiswa yang puas dan tidak puas adalah persepsi mereka layanan petugas perpustakaan adalah kemutakhiran koleksi buku yang ada di perpustakaan, kelengkapan sarana dan fasilitas, keramahan dan kesopanan petugas serta kemudahan dalam pencarian koleksi buku. Selanjutnya, nilai tersebut dibandingkan dengan cut off score (nilai batas) untuk mengetahui apakan mahasiswa puas atau tidak dengan pelayanan yang ada secara umum. Nilai cut off score dapat dihitung sebagai berikut:

$\begin{aligned} \text { Zcu }=\frac{N_{A} Z_{B}+N_{B} Z_{A}}{N_{A}+N_{B}} & =\frac{(104 x(-0,661))+(66 \times 1.062)}{270} \\ & =\mathbf{0 . 0 0 4 9 9}\end{aligned}$

Jika angka skor kasus diatas cutt off score, maka mahasiswa cenderung puas terhadap layanan perpustakaan dan sebaliknya. Pada Tabel 4.4 akan disajikan beberapa contoh penilaian mahasiswa terhadap keempat atribut layanan tersebut. 
Tabel 5. Contoh penilaian mahasiswa terhadap performance atribut layanan perpustakaan

\begin{tabular}{|l|l|l|l|l|l|}
\hline $\begin{array}{c}\text { Kemutakhiran } \\
\text { koleksi bahan } \\
\text { di } \\
\text { perpustakaan }\end{array}$ & $\begin{array}{c}\text { Kelengkapan } \\
\text { sarana }\end{array}$ & $\begin{array}{c}\text { Keramahan } \\
\text { dan } \\
\text { kesopanan } \\
\text { petugas }\end{array}$ & $\begin{array}{c}\text { Kemudahan } \\
\text { dalam pencarian } \\
\text { koleksi buku }\end{array}$ & Nilai & \multicolumn{1}{c|}{$\begin{array}{c}\text { secara } \\
\text { umum }\end{array}$} \\
\hline 4 & 4 & 4 & 4 & -0.332 & tidak puas \\
\hline 6 & 6 & 6 & 6 & 2.158 & puas \\
\hline 3 & 3 & 3 & 3 & -1.577 & tidak puas \\
\hline 6 & 6 & 3 & 3 & 0.097 & puas \\
\hline 3 & 3 & 3 & 3 & -1.577 & tidak puas \\
\hline 5 & 5 & 4 & 4 & 0.226 & puas \\
\hline
\end{tabular}

Model tersebut menjelaskan pada layanan perpustakaan, persepsi mahasiswa tentang kemutakhiran koleksi buku di perpustakaan, kelengkapan sarana dan fasilitas, keramahan dan kesopanan petugas serta kemudahan dalam pencarian koleksi buku petugas perpustakaan mempengaruhi kepuasan atau ketidak puasan terhadap pelayanan ini secara umum. Jika mahasiswa menganggap bahwa keempat atribut itu biasa saja atau diberi skor 4 dengan skala 1 sampai 7 maka mahasiswa itu cenderung tidak puas terhadap layanan perpustakaan secara keseluruhan. Namun jika dalam keempat atribut layanan tadi mahasiswa merasakan sangat puas dengan skor 5 pada masing-masing atribut layanan, maka mahasiswa tersebut cenderung puas terhadap layanan perpustakaan. Lain halnya jika pada koleksi bahan di perpustakaan sangat mutakhir dengan skor 6, sarana dan fasilitas dianggap sudah lengkap dengan skor 6 meskipun petugas dianggap kurang ramah dan pencarian koleksi buku masih agak sulit dengan skor 3, mahasiswa masih cenderung merasa puas terhadap layanan perpustakaan ini secara keseluruhan. Namun sebaliknya, jika mahasiswa merasa koleksi bahan atau buku di perpustakaan kurang mutakhir dan sarana serta fasilitas kurang lengkap, masing-masing dengan skor 3, meskipun petugas sudah dirasa sangat ramah dan pencarian koleksi buku sangat mudah yang diberi skor 6, mahasiswa masih cenderung merasa tidak puas terhadap layanan perpustakaan secara umum. 
139 | al-Khwarizmi, Volume III, Edisi 1, Maret 2015, Hal. 123 - 142.

5) Indeks kepuasan mahasiswa STAIN Palopo terhadap layanan fasilitas perpustakaan.

Indeks kepuasan mahasiswa dihitung dengan mengalikan skor gap dengan pembobotnya. Pembobot didasarkan pada skala kepentingan, yaitu perhitungan dari matriks proporsi pada thurstone case $\mathrm{V}$ yang jika dijumlahkan hasilnya adalah satu. Perhitungan indeks dapat dilihat pada Tabel 6

Tabel 6 Indeks kepuasan mahasiswa terhadap layanan fasilitas perpustakaan

\begin{tabular}{|l|l|l|l|l|}
\hline No & Variabel & Rataan gap & Pembobot & Indeks \\
\hline 1 & $\begin{array}{l}\text { Pengetahuan petugas tentang jenis buku yang } \\
\text { ada di perpustakaan }\end{array}$ & -2.7294 & 0.102104 & -0.27868 \\
\hline 2 & Kemudahan prosedur layanan & -1.8706 & 0.081013 & -0.15154 \\
\hline 3 & Ketepatan jam buka dan jam tutup & -2.3706 & 0.063272 & -0.14999 \\
\hline 4 & $\begin{array}{l}\text { Kecepatan dan ketepatan pelayanan transaksi } \\
\text { peminjaman buku }\end{array}$ & -2.2647 & 0.066517 & -0.15064 \\
\hline 5 & $\begin{array}{l}\text { Kemampuan petugas berkomunikasi dengan } \\
\text { mahasiswa }\end{array}$ & -2.6294 & 0.029621 & -0.07789 \\
\hline 6 & Kemutakhiran koleksi bahan di perpustakaan & -2.5118 & 0.087032 & -0.2186 \\
\hline 7 & $\begin{array}{l}\text { Kesesuain koleksi dengan kebutuhan } \\
\text { mahasiswa }\end{array}$ & -2.2059 & 0.078658 & -0.17351 \\
\hline 8 & Kemudahan dalam pencarian koleksi buku & -1.9 & 0.074838 & -0.14219 \\
\hline 9 & Kesesuain antara label di buku dan katalog & -2.1471 & 0.054323 & -0.11663 \\
\hline 10 & Kebersihan perpustakaan secara umum & -1.7529 & 0.060603 & -0.10623 \\
\hline 11 & Kenyamanan ruang baca & -2.5471 & 0.04888 & -0.1245 \\
\hline 12 & Kelengkapan sarana dan fasilitas & -2.7765 & 0.059085 & -0.16405 \\
\hline 13 & $\begin{array}{l}\text { Petugas memakai seragam dengan tanda } \\
\text { pengenal }\end{array}$ & -2.4941 & 0.084572 & -0.21093 \\
\hline 14 & Keramahan petugas & -1.7529 & 0.066046 & -0.11577 \\
\hline
\end{tabular}

Indeks kepuasan mahasiswa pada layanan perpustakaan yang paling tinggi adalah pada kemampuan petugas berkomunikasi dengan mahasiswa, sedangkan yang kedua adalah kebersihan perpustakaan. Angka indeks yang paling rendah adalah pengetahuan petugas tentang jenis buku yang ada di perpustakaan, serta kemutakhiran koleksi bahan di perpustakaan. Indeks kepuasan diharapkan adalah nilai minus mendekati nol atau bahkan nol.

\section{Pembahasan}

Seperti yang terlihat pada model penilaian performance secara bersama-sama pada kemutakhiran koleksi bahan perpustakaan, 
kelengkapan sarana dan fasilitas, keramahan dan kesopanan petugas serta kemudahan dalam pencarian koleksi buku mempengaruhi mahasiswa untuk merasa puas atau tidak puas terhadap layanan perpustakaan secara umum.

Perhitungan nilai indeks yang menggabungkan antara skor gap dan prioritas layanan dapat memberikan referensi bagi pihak manajemen untuk memprioritaskan variabel mana yang diprioritaskan untuk diperbaiki. Nilai indeks paling rendah yang paling mendapatkan perhatian utama. Urutan perbaikan prioritas layanan dapat dilihat pada tabel 7

Tabel 7 Prioritas variabel yang harus ditingkatkan pada layanan perpustakaan

\begin{tabular}{|l|l|l|}
\hline No & Variabel & Indeks \\
\hline 1 & Pengetahuan petugas tentang jenis buku yang ada di & -.278680 \\
2 & perpustakaan & \\
3 & Kemutakhiran koleksi bahan di perpustakaan & -.218600 \\
4 & Petugas memakai seragam dan tanda pengenal & -.210930 \\
5 & Kelengkapan sarana dan fasilitas & -.173510 \\
6 & Kemudahan prosedur pelayanan & -.164050 \\
7 & Kecepatan dan ketepatan pelayanan transaksi peminjaman & -.151540 \\
8 & buku & -.150640 \\
9 & Ketepatan jam buka dan jam tutup & -.149990 \\
10 & Kemudahan dalam pencarian koleksi buku & -.142190 \\
11 & Kenyamanan ruang baca & -.124500 \\
12 & Kesesuaian antara label dan buku katalog & -.116630 \\
13 & Keramahan dan kesopanan petugas & -.115770 \\
14 & Kebersihan perpustakaan & -.106230 \\
& Kemampuan petugas berkomunikasi dengan mahasiswa & -.077890 \\
\hline
\end{tabular}

\section{Kesimpulan dan Saran}

Dari hasil evaluasi kepuasan mahasiswa terhadap layanan perpustakaan, dapat disimpulkan:

a. Mahasiswa pengguna layanan perpustakaan paling banyak adalah perempuan $(74.7 \%) .70 .6 \%$ mahasiswa tinggalnya kos, $26.5 \%$ tinggal dirumah sendiri dan sisanya tinggal di rumah saudara. 51.8\% mahasiswa pengeluarannya antara Rp.100.000,sampai Rp.300.000, 27.1\% diatas Rp. 400.000,-, 17.6\% antara Rp.300.000,- sampai Rp.400.000,- dan 3.5\% dibawah Rp.100.000,-. Dalam satu bulan, $46.5 \%$ mahasiswa mengunjungi perpustakaan satu kali dan $40.6 \%$ 2-3 kali.

b. Atribut layanan yang membedakan mahasiswa yang puas dan tidak puas adalah persepsi mereka terhadap kemutakhiran koleksi bahan di perpustakaan, kelengkapan sarana dan fasilitas, 
141 | al-Khwarizmi, Volume III, Edisi 1, Maret 2015, Hal. 123 - 142.

keramahan dan kesopanan petugas serta kemudahan dalam pencarian koleksi buku.

c. Indeks kepuasan mahasiswa terhadap atribut layanan perpustakaan yang paling rendah adalah pengetahuan petugas tentang jenis buku yang ada di perpustakaan dan yang paling tinggi adalah kemampuan petugas berkomunikasi dengan mahasiswa.

Untuk peningkatan pelayanan perpustakaan, maka perlu diadakan peningkatan seluruh atribut layanan. Prioritas atribut layanan yang ditingkatkan pertama kali adalah pengetahuan petugas tentang jenis buku yang ada di perpustakaan. Demikian pula dengan kemutakhiran koleksi bahan di perpustakaan.

\section{DAFTAR PUSTAKA}

Aritonang, 2002, Kepuasan Pelanggan, Gramedia Pustaka Utama, Jakarta.

Ancok, Djamaluddin, dan Singarimbun, 1995. Metode Penelitian Survai. LP3ES Jakarta.

Arisutha, Damartaji, 2005. Dimensi Kualitas Pelayanan. Penerbit Gramedia Pustaka, Jakarta.

Barata, Atep. D., 2001. Pelayanan Prima. Elex Media Komputindo, Jakarta.

Dekker, A. Steven, 2001. Measure Service Quality: Reexamination and Extension. Journal of Marketing. Vol. 56. July, 55-68. (Diterjemahkan oleh Sutanto).

Dillon W. R., Goldstein M., 1982, Discrete Discriminant Analysis, John Wiley \& Sons. New York.

Fathoni, 2009, Analisis Kualitas Layanan Sistem Informasi Menggunakan Metode Servqual, Jurnal Ilmiah Universitas Sriwijaya, Riau.

Engel, James, 1990. (Diterjemahkan oleh Purwoko) Satisfaction; A Behavioral Perspective On The Consumer. Mc-Graw Hill Companies Inc., USA.

Gaspersz, Vincent, 2003. Manajemen Bisnis Total - Total Quality Management. Penerbit PT. Gramedia Pustaka Utama, Jakarta.

Gerson, Richard F. 2002, Mengukur Kepuasan Pelanggan, PPM Griffin, Jill.Irawan Handi, 2003, 10 Prinsip Kepuasan Pelanggan, PT. Elex Media Komputindo, Jakarta.

Gronroos, Michael, 1990. Perceived Service Quality Model. Published Ohio University Press, California. 
Hesketts, Robert, 1990. Service Profit Chain Model. Prentice Hall, California Press.

Kotler P, Gary Armstrong, 1997, Prinsip-Prinsip Pemasaran, Terjemahan, Edisi Ketiga, Jakarta.

Margaretha, 2003. Kualitas Pelayanan: Teori dan Aplikasi. Penerbit Mandar Maju, Jakarta.

Marcel, Davidson, 2003. Service Quality in Concept and Theory. Published by American Press, USA.

Martul, Shadiqqin, 2004. Implementasi Dimensi Kualitas Pelayanan Konsumen. Penerbit Sinar Grafika,Jakarta.

Rangkuti, Freddy, 2003. Konsep Pengukuran Kepuasan. Penerbit PT. Gramedia Pustaka Utama, Jakarta.

Sunyoto, Hamingpraja, 2004. Jaminan Kualitas Pelayanan Konsumen. Penerbit Liberty, Yogyakarta.

Tjiptono, Fandy, 2004. Kepuasan dalam Pelayanan. Penerbit Salemba Empat, Jakarta.

Zeithaml, Bitner, 1990. (Diterjemahkan oleh Purwoko) The Concept of Customer Satisfaction. The McGraw-Hill Companies. Inc. USA. 